\title{
Sarcoidosis Presenting with Primary Pancreatic Manifestations: A Case Report and Review of the Literature
}

\author{
Eisar Al-Sukhni ${ }^{*}$, Jingxin Qiu ${ }^{2}$, Emmanuel Gabriel ${ }^{1}$ and Steven N Hochwald ${ }^{1}$
}

${ }^{1}$ Department of Surgical Oncology, Roswell Park Cancer Institute, Elm and Carlton Streets, USA

${ }^{2}$ Department of Pathology and Laboratory Medicine, Roswell Park Cancer Institute, Elm and Carlton Streets, USA

\begin{abstract}
Background: Pancreatic sarcoidosis in the absence of systemic sarcoidosis is a rare entity with few reported cases. Most described cases are in black females and typically involve the head of the pancreas. This report describes a case of sarcoidosis involving the tail of the pancreas in a Caucasian male.

Case Presentation: A previously healthy 48 year old Caucasian male presented with abdominal pain following an episode of heavy alcohol ingestion. Serum amylase was elevated and imaging was consistent with acute pancreatitis. Workup ruled out gallstones or autoimmune pancreatitis and his presentation was attributed to alcohol use. Despite abstaining from further alcohol intake, his abdominal pain persisted for several weeks, and subsequent imaging revealed persistent pancreatitis with narrowing of the pancreatic duct in the tail with an associated area of hypoechogenicity. FNA of this region showed rare benign ductal epithelial cells without evidence of malignancy. He was offered resection for his ongoing symptoms and to rule out a malignancy as an underlying etiology. He underwent laparoscopic distal pancreatectomy and splenectomy. Pathology from the resected specimen showed non-necrotizing granulomas involving the pancreas, spleen and the majority of 25 resected lymph nodes. Acid-fast bacteria and Gomori methenamine silver stains were negative for fungal or mycobacterial organisms and there was no evidence of polarizable materials within these granulomas. These findings are consistent with sarcoidosis. The patient recovered and was discharged without complication. He was subsequently referred to a rheumatologist for further workup and management.
\end{abstract}

Conclusions: Sarcoidosis can present with isolated pancreatic symptoms and may be difficult to distinguish from other causes of pancreatitis. In the absence of systemic disease, surgery alone may be both diagnostic and therapeutic.

\section{Introduction}

Sarcoidosis is an inflammatory disorder characterized by the presence of granulomatous infiltration of multiple organs, most commonly the lungs, skin, joints or eyes. The etiology is unclear but has been hypothesized to involve an exaggerated cell-mediated immune reaction to an unknown antigen. Clinically evident gastrointestinal manifestations have been reported in fewer than $1 \%$ of patients with sarcoidosis. Here, we report a case of sarcoidosis presenting with pancreatitis in a patient with no known history of sarcoidosis, and we summarize the existing literature to describe the presentation and clinical course of patients with this unusual disease.

\section{Case Report}

An otherwise healthy 48 year old Caucasian male presented to the gastroenterology service with complaints of chronic left upper quadrant abdominal pain following an episode of significant alcohol intake 3 months earlier. CT abdomen/pelvis at initial presentation showed mild enlargement of the pancreas with surrounding inflammation and fat stranding, consistent with acute pancreatitis. Serum total bilirubin was $0.5 \mathrm{mg} / \mathrm{dL}$ and abdominal ultrasound showed no evidence of gallstones. Serum amylase and lipase were both mildly elevated to 128 $\mathrm{U} / \mathrm{L}$ and $239 \mathrm{U} / \mathrm{L}$, respectively. Ca $19-9$ was $26 \mathrm{U} / \mathrm{mL}$, within normal limits. Serum IgG4 level to rule out autoimmune pancreatitis was also normal at 0.39 . His pancreatitis was attributed to alcohol intake and he was managed conservatively.

Despite abstaining from further alcohol intake, his pain persisted and several weeks later, repeat CT abdomen/pelvis showed persistent mild peripancreatic stranding and a small amount of fluid with pseudocysts in the body/tail (Figure 1). The pancreatic duct was irregular and dilated in the tail. EGD with EUS was performed to rule out a pancreatic mass as a cause of his pancreatic duct dilation. This showed a $21 \times 19 \mathrm{~mm}$ region of diffuse hypoechogenicity in the pancreatic tail with abrupt dilation of the pancreatic duct distal to this region. There was ongoing stranding consistent with pancreatitis. FNA of the hypoechogenic region in the pancreatic tail showed rare benign ductal epithelial cells without evidence of malignancy.

He continued to have intermittent recurrent exacerbations of abdominal pain which were manageable with dietary restriction to a clear liquid or low-fat diet. He was seen by the surgical service and offered distal pancreatectomy for his symptoms versus continued observation; he opted for the latter. Interval surveillance scans 2 and 5 months later showed further decrease of stranding and inflammatory change involving and surrounding the distal pancreatic body and tail and decrease in the pseudocysts, although a $7 \mathrm{~mm}$ low-density area persisted in the distal pancreatic body with pancreatic duct dilation noted distal to this lesion. Given these findings and his ongoing symptoms in the absence of another clear etiology, it was recommended that he undergo resection both to address his symptoms and to rule out

*Corresponding author: Eisar Al-Sukhni, Department of Surgical Oncology, Roswell Park Cancer Institute, Elm and Carlton Streets, USA, Tel: 716-845-8574; Fax: 716-845-1244; E-mail: eisar.al-sukhni@roswellpark.org

Received May 22, 2016; Accepted June 24, 2016; Published June 26, 2016

Citation: Al-Sukhni E, Qiu J, Gabriel E, Hochwald SN (2016) Sarcoidosis Presenting with Primary Pancreatic Manifestations: A Case Report and Review of the Literature. J Mol Biomark Diagn 7: 290. doi:10.4172/2155-9929.1000290

Copyright: (c 2016 Al-Sukhni E, et al. This is an open-access article distributed under the terms of the Creative Commons Attribution License, which permits unrestricted use, distribution, and reproduction in any medium, provided the original author and source are credited. 
an underlying pancreatic duct stricture or neoplasm as a cause for his recurrent pancreatitis.

He consented to proceed with surgery and underwent laparoscopic distal pancreatectomy and splenectomy. Intraoperatively, the liver appeared fibrotic and a liver biopsy was performed. The pancreas itself appeared firm in the tail of the pancreas and intraoperative ultrasound demonstrated focal dilation of the duct in this region.

Pathology showed non-necrotizing granulomas involving the pancreas, spleen and the majority of 25 resected lymph nodes as well as the liver biopsy (Figure 2). Acid-fast bacteria (AFB) and Gomori methenamine silver (GMS) stains were negative for fungal or mycobacterial organisms. There was no evidence of polarizable materials within these granulomas. The overall findings are consistent with sarcoidosis.

In follow up, the patient reported improvement in his abdominal symptoms. CT chest was negative for pulmonary manifestations of sarcoidosis. The patient was referred to a rheumatologist for further evaluation.

\section{Discussion}

Sarcoidosis involving the pancreas is very rare, particularly in the absence of systemic manifestations. A review of the English language literature identified a limited number of cases of sarcoidosis presenting with pancreatic symptoms without a known history of the disease, the majority of which have been published in the past three decades [114] (Table 1). There is a slight preponderance of females and African Americans among reported cases and most present in the fifth to seventh decades of life. The most common presenting symptoms are abdominal pain, nausea/vomiting, jaundice and weight loss. In contrast to our patient, the vast majority of symptomatic cases involve the head of the pancreas. Imaging typically reveals a hypodense mass with indistinct margins or pancreatic enlargement or fullness without a discrete mass. Regional lymph nodes are frequently involved and can be significantly enlarged. Frequently, the liver is also concurrently involved.

Preoperative biopsy is rarely helpful and operative exploration is typically required to evaluate the extent of disease and to obtain sufficient tissue to establish a diagnosis. Systemic sarcoidosis is diagnosed on the basis of identifying non-caseating epithelioid granulomas in all of several affected organs or tissues. The diagnosis is relatively straightforward in the typical clinical scenario with multisystem involvement including pulmonary complaints and skin, joint or eye involvement, but it can be more problematic when only one organ is involved, since the histologic features are not pathognomonic for sarcoidosis. Indeed, non-caseating granulomas can be found in the presence of some malignancies, including pancreatic adenocarcinoma [15]; thus, formal resection is often necessary to rule out pancreatic malignancy in patients without clear evidence of sarcoidosis elsewhere.

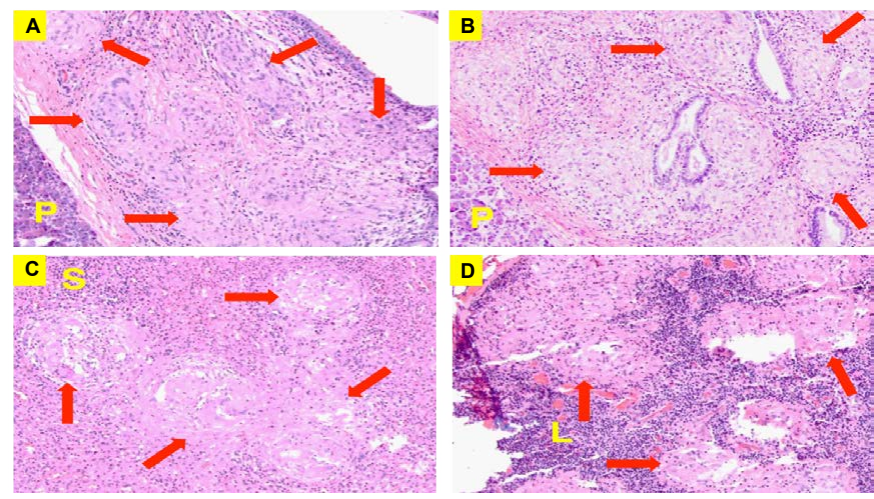

Figure 1: CT abdomen/pelvis image demonstrating persistent dilation of the pancreatic duct in the tail of the pancreas (red arrow).

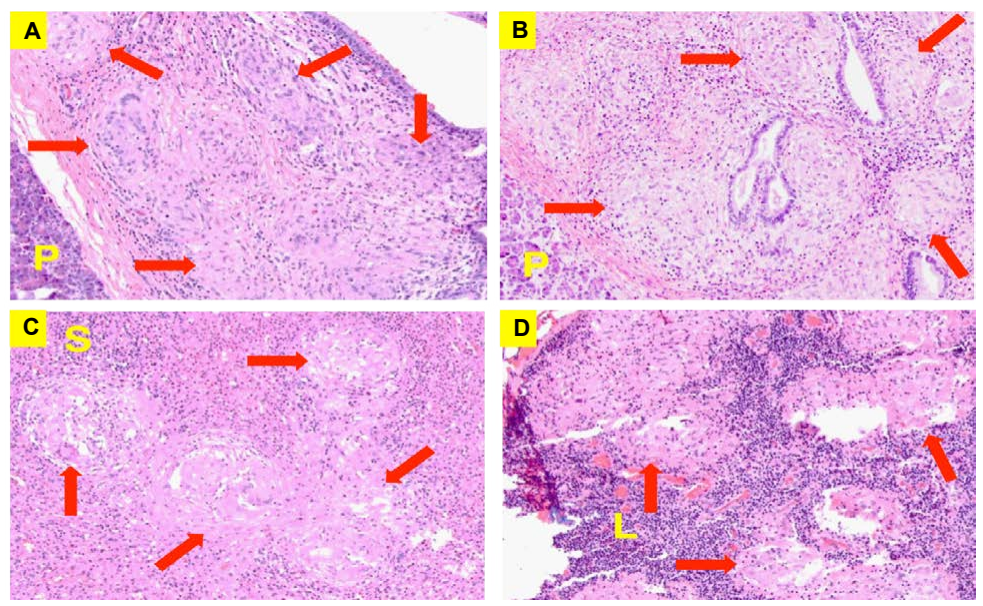

Figure 2: Microscopic images (200x). A and B. Pancreatic tissue (P) with confluent non-necrotizing granulomas (red arrows). C. Spleen (S) with focal non-necrotizing granulomas (red arrows). D. Lymph nodes (L) With non-necrotizing granulomas (red arrows). 
Citation: Al-Sukhni, Qiu J, Gabriel E, Hochwald SN (2016) Sarcoidosis Presenting with Primary Pancreatic Manifestations: A Case Report and Review of the Literature. J Mol Biomark Diagn 7: 290. doi:10.4172/2155-9929.1000290

Page 3 of 4

\begin{tabular}{|c|c|c|c|c|c|c|c|c|c|c|c|}
\hline $\begin{array}{l}\text { Report } \\
\text { (reference) }\end{array}$ & Sex & Age & $\begin{array}{l}\text { Ethnicity/ } \\
\text { Country }\end{array}$ & Presentation & $\begin{array}{l}\text { Location } \\
\text { in } \\
\text { pancreas }\end{array}$ & $\begin{array}{l}\text { Other sites } \\
\text { of disease }\end{array}$ & Radiologic findings & Labs & Diagnosis & Management & Outcome \\
\hline $\begin{array}{l}\text { Mayne } \\
{[1]}\end{array}$ & M & 52 & UK & $\begin{array}{l}\text { Jaundice, } \\
\text { back pain, } \\
\text { weight loss }\end{array}$ & Head & $\begin{array}{l}\text { Regional } \\
\text { nodes }\end{array}$ & $\begin{array}{l}\text { Low attenuation } \\
\text { pancreatic head lesion } \\
\text { with biliary dilation }\end{array}$ & $\begin{array}{l}\text { Elevated Ca } \\
19-9\end{array}$ & $\begin{array}{l}\text { Whipple } \\
\text { specimen }\end{array}$ & $\begin{array}{l}\text { Chemotherapy } \\
\text { followed by } \\
\text { Whipple }\end{array}$ & Not reported \\
\hline $\begin{array}{l}\text { Schauer } \\
{[2]}\end{array}$ & M & 29 & Germany & $\begin{array}{l}\text { Abdominal } \\
\text { pain, jaundice }\end{array}$ & Head & $\begin{array}{l}\text { Mediastinal } \\
\text { nodes }\end{array}$ & $\begin{array}{l}\text { Enlarged pancreatic } \\
\text { head with homogeneous } \\
\text { hypodensity, no definite } \\
\text { mass }\end{array}$ & $\begin{array}{l}\text { Elevated } \\
\text { bilirubin, ALP } \\
\text { and GGT, } \\
\text { normal lipase, } \\
\text { normal Ca 19-9 }\end{array}$ & $\begin{array}{l}\text { Whipple } \\
\text { specimen }\end{array}$ & Whipple & $\begin{array}{l}\text { Free of } \\
\text { symptoms } 54 \\
\text { months postop }\end{array}$ \\
\hline $\begin{array}{l}\text { Wijkstrom } \\
{[3]}\end{array}$ & $\mathrm{F}$ & 49 & $\begin{array}{l}\text { African- } \\
\text { American }\end{array}$ & $\begin{array}{l}\text { Abdominal } \\
\text { pain, } \\
\text { anorexia, } \\
\text { pruritus, } \\
\text { weight loss }\end{array}$ & Head & None & $\begin{array}{l}\text { Hypodense ill-defined } \\
\text { pancreatic head mass } \\
\text { surrounding hepatic } \\
\text { artery and encasing } \\
\text { portal vein }\end{array}$ & $\begin{array}{l}\text { Elevated } \\
\text { bilirubin, ALP } \\
\text { and Ca 19-9; } \\
\text { autoimmune } \\
\text { anti-bodies } \\
\text { negative }\end{array}$ & $\begin{array}{l}\text { Laparotomy } \\
\text { and biopsy }\end{array}$ & $\begin{array}{l}\text { Steroids } \\
\text { followed } \\
\text { by bypass } \\
\text { for biliary } \\
\text { obstruction }\end{array}$ & $\begin{array}{l}\text { Free of } \\
\text { symptoms } 5 \\
\text { years following } \\
\text { treatment }\end{array}$ \\
\hline $\begin{array}{l}\text { Wellner } \\
{[4]}\end{array}$ & $\mathrm{F}$ & 68 & Germany & $\begin{array}{l}\text { Abdominal } \\
\text { pressure, } \\
\text { vomiting, } \\
\text { dyspnea }\end{array}$ & Head & $\begin{array}{l}\text { Mediastinal } \\
\text { nodes, } \\
\text { subpleural } \\
\text { nodules }\end{array}$ & $\begin{array}{l}\text { Rounded pancreatic } \\
\text { head soft tissue mass } \\
\text { with enlarged peri- } \\
\text { pancreatic and periportal } \\
\text { nodes }\end{array}$ & $\begin{array}{l}\text { Routine labs } \\
\text { normal }\end{array}$ & $\begin{array}{l}\text { Laparotomy } \\
\text { and biopsy }\end{array}$ & $\begin{array}{l}\text { Steroids and } \\
\text { azathioprine }\end{array}$ & $\begin{array}{l}\text { Free of } \\
\text { symptoms } 1 \\
\text { year postop }\end{array}$ \\
\hline $\begin{array}{l}\text { Harder } \\
{[5]}\end{array}$ & M & 71 & Germany & $\begin{array}{l}\text { Abdominal } \\
\text { pain, fatigue }\end{array}$ & Head & $\begin{array}{l}\text { Liver, peri- } \\
\text { pancreatic } \\
\text { nodes }\end{array}$ & $\begin{array}{l}\text { Pancreatic head } \\
\text { mass with stenosis of } \\
\text { pancreatic duct }\end{array}$ & $\begin{array}{l}\text { Elevated Ca 19- } \\
9, \text { normal liver } \\
\text { and pancreatic } \\
\text { enzymes, IgG } \\
\text { normal }\end{array}$ & $\begin{array}{l}\text { Whipple } \\
\text { specimen }\end{array}$ & $\begin{array}{l}\text { Whipple } \\
\text { followed by } \\
\text { steroids }\end{array}$ & $\begin{array}{l}\text { Symptoms } \\
\text { resolved }\end{array}$ \\
\hline Caceres [6] & M & 60 & USA & $\begin{array}{l}\text { Abdominal } \\
\text { pain, jaundice, } \\
\text { weight loss }\end{array}$ & Head & $\begin{array}{l}\text { Peri- } \\
\text { pancreatic } \\
\text { and para- } \\
\text { aortic } \\
\text { nodes }\end{array}$ & $\begin{array}{l}\text { Hypodensity in } \\
\text { pancreatic head, CBD } \\
\text { stricture }\end{array}$ & $\begin{array}{l}\text { Elevated } \\
\text { bilirubin, ALP, } \\
\text { AST and ALT, } \\
\text { normal Ca 19-9 }\end{array}$ & $\begin{array}{l}\text { Whipple } \\
\text { specimen }\end{array}$ & $\begin{array}{l}\text { Whipple } \\
\text { followed by } \\
\text { steroids for } \\
\text { altered mental } \\
\text { status }\end{array}$ & $\begin{array}{l}\text { Improved } \\
\text { mental status } \\
1 \text { year after } \\
\text { treatment }\end{array}$ \\
\hline $\begin{array}{l}\text { Baroni } \\
{[7]}\end{array}$ & $\mathrm{F}$ & 42 & $\begin{array}{l}\text { African- } \\
\text { American }\end{array}$ & $\begin{array}{l}\text { Abdominal } \\
\text { pain, vomiting, } \\
\text { weight loss, } \\
\text { fevers, } \\
\text { fatigue, } \\
\text { thirst, lower } \\
\text { extremity } \\
\text { edema }\end{array}$ & Body & $\begin{array}{l}\text { Portal } \\
\text { nodes }\end{array}$ & $\begin{array}{l}\text { Multiple pancreatic } \\
\text { masses with slightly } \\
\text { increased signal intensity } \\
\text { on T2 weighted imaging } \\
\text { and slightly decreased } \\
\text { signal intensity on non } \\
\text { contrast T1 imaging } \\
\text { relative to pancreatic } \\
\text { parenchyma }\end{array}$ & $\begin{array}{l}\text { Elevated LFT's } \\
\text { (not reported), } \\
\text { normal amylase }\end{array}$ & $\begin{array}{l}\text { Laparotomy } \\
\text { and biopsy }\end{array}$ & Steroids & $\begin{array}{l}\text { Resolution } \\
\text { of pancreatic } \\
\text { masses } 3 \\
\text { months after } \\
\text { treatment }\end{array}$ \\
\hline $\begin{array}{l}\text { Romboli } \\
{[8]}\end{array}$ & M & 62 & Italy & $\begin{array}{l}\text { Malaise, } \\
\text { asthenia, } \\
\text { abdominal } \\
\text { swelling, slight } \\
\text { fever x1 year }\end{array}$ & Diffuse & $\begin{array}{l}\text { Liver, } \\
\text { lungs, } \\
\text { peri celiac } \\
\text { nodes }\end{array}$ & $\begin{array}{l}\text { No pancreatic mass } \\
\text { on CT; pancreatic } \\
\text { parenchyma with a } \\
\text { lobular pattern and } \\
\text { hyperechoic pseudo- } \\
\text { septae compatible with } \\
\text { pancreatic inflammation } \\
\text { on EUS }\end{array}$ & $\begin{array}{l}\text { Pan-cytopenia } \\
\text { with elevated } \\
\text { acute phase } \\
\text { reactants, } \\
\text { transaminases } \\
\text { and LDH, } \\
\text { elevated Ca } \\
19-9\end{array}$ & Liver biopsy & Steroids & $\begin{array}{l}\text { Improved } \\
\text { clinical } \\
\text { symptoms, } \\
\text { ongoing steroid } \\
\text { treatment }\end{array}$ \\
\hline $\begin{array}{l}\text { Frank } \\
\text { [9] }\end{array}$ & $\mathrm{F}$ & 40 & $\begin{array}{l}\text { African- } \\
\text { American }\end{array}$ & $\begin{array}{l}\text { Abdominal } \\
\text { pain, jaundice }\end{array}$ & Head & None & $\begin{array}{l}\text { Fullness in pancreatic } \\
\text { head with effacement of } \\
\text { portal vein and CBD }\end{array}$ & Not reported & $\begin{array}{l}\text { Whipple } \\
\text { specimen }\end{array}$ & Whipple & $\begin{array}{l}\text { Free of } \\
\text { symptoms } 12 \\
\text { months postop }\end{array}$ \\
\hline $\begin{array}{l}\text { Bacal } \\
{[10]}\end{array}$ & M & 54 & $\begin{array}{l}\text { Caucasian/ } \\
\text { USA }\end{array}$ & Jaundice & Head & Liver & $\begin{array}{l}\text { CBD dilation at level of } \\
\text { pancreatic head }\end{array}$ & $\begin{array}{l}\text { Elevated } \\
\text { bilirubin, ALP } \\
\text { and GGT }\end{array}$ & $\begin{array}{l}\text { Whipple } \\
\text { specimen }\end{array}$ & $\begin{array}{l}\text { Whipple } \\
\text { followed by } \\
\text { steroids } 1 \\
\text { year later for } \\
\text { development } \\
\text { of jaundice }\end{array}$ & $\begin{array}{l}\text { Developed } \\
\text { jaundice } 1 \text { year } \\
\text { post Whipple, } \\
\text { treated } \\
\text { successfully } \\
\text { with steroids }\end{array}$ \\
\hline $\begin{array}{l}\text { Siavellis } \\
{[11]}\end{array}$ & M & 61 & $\begin{array}{l}\text { African- } \\
\text { American }\end{array}$ & $\begin{array}{l}\text { Jaundice, } \\
\text { weight loss }\end{array}$ & Head & None & $\begin{array}{l}\text { Pancreatic head mass } \\
\text { with double duct sign }\end{array}$ & $\begin{array}{l}\text { Elevated } \\
\text { bilirubin and } \\
\text { ALP, normal } \\
\text { amylase }\end{array}$ & $\begin{array}{l}\text { Whipple } \\
\text { specimen }\end{array}$ & Whipple & $\begin{array}{l}\text { Free of } \\
\text { symptoms } 15 \\
\text { months postop }\end{array}$ \\
\hline $\begin{array}{l}\text { Bonhomme } \\
{[12]}\end{array}$ & M & 76 & Belgium & $\begin{array}{l}\text { Fatigue, } \\
\text { weight loss, } \\
\text { post prandial } \\
\text { pain }\end{array}$ & $\begin{array}{l}\text { Head and } \\
\text { tail }\end{array}$ & $\begin{array}{l}\text { Lung, } \\
\text { peritoneum, } \\
\text { duodenum, } \\
\text { gallbladder }\end{array}$ & $\begin{array}{l}\text { Hypodense lesions in } \\
\text { pancreatic head and tail }\end{array}$ & $\begin{array}{l}\text { Elevated } \\
\text { bilirubin and } \\
\text { GGT, normal } \\
\text { amylase and } \\
\text { lipase }\end{array}$ & $\begin{array}{l}\text { Laparotomy } \\
\text { and biopsy }\end{array}$ & Steroids & $\begin{array}{l}\text { Free symptoms } \\
\text { after } 3 \text { months }\end{array}$ \\
\hline $\begin{array}{l}\text { Soyer } \\
{[13]}\end{array}$ & $\mathrm{F}$ & 51 & $\begin{array}{l}\text { African- } \\
\text { American }\end{array}$ & $\begin{array}{l}\text { Abdominal } \\
\text { pain, weight } \\
\text { loss, nausea, } \\
\text { vomiting, flank } \\
\text { pain }\end{array}$ & Head & $\begin{array}{l}\text { Not } \\
\text { reported }\end{array}$ & $\begin{array}{l}\text { Hypo-attenuating } \\
\text { pancreatic head mass } \\
\text { with periportal, periceliac } \\
\text { and retro-peritoneal } \\
\text { nodes }\end{array}$ & $\begin{array}{l}\text { Elevated } \\
\text { bilirubin, ALP } \\
\text { and liver } \\
\text { enzymes }\end{array}$ & $\begin{array}{l}\text { Laparotomy } \\
\text { and biopsy }\end{array}$ & $\begin{array}{l}\text { Surgical } \\
\text { bypass and } \\
\text { steroids }\end{array}$ & $\begin{array}{l}\text { Free of } \\
\text { symptoms } \\
10 \text { months } \\
\text { after initial } \\
\text { presentation }\end{array}$ \\
\hline $\begin{array}{l}\text { Brady } \\
{[14]}\end{array}$ & $\mathrm{F}$ & 67 & $\begin{array}{l}\text { Caucasian/ } \\
\text { USA }\end{array}$ & $\begin{array}{l}\text { Abdominal } \\
\text { pain, nausea }\end{array}$ & Head & $\begin{array}{l}\text { Not } \\
\text { reported }\end{array}$ & $\begin{array}{l}\text { Enlarged pancreatic } \\
\text { head }\end{array}$ & $\begin{array}{l}\text { Normal bilirubin, } \\
\text { elevated ALP } \\
\text { and amylase }\end{array}$ & $\begin{array}{l}\text { Whipple } \\
\text { specimen }\end{array}$ & $\begin{array}{l}\text { Whipple } \\
\text { followed by } \\
\text { steroids }\end{array}$ & $\begin{array}{l}\text { Free of } \\
\text { symptoms } 3 \\
\text { years postop }\end{array}$ \\
\hline
\end{tabular}

Table 1: Reported cases of sarcoidosis presenting with primary pancreatic symptoms. 
Citation: Al-Sukhni, Qiu J, Gabriel E, Hochwald SN (2016) Sarcoidosis Presenting with Primary Pancreatic Manifestations: A Case Report and Review of the Literature. J Mol Biomark Diagn 7: 290. doi:10.4172/2155-9929.1000290

Page 4 of 4

Despite applying multiple advanced diagnostic modalities, it was not possible to rule out malignancy in this patient. Our experience suggests that surgery plays an important role in the diagnosis of pancreatic sarcoidosis and will likely continue to do so in future cases of patients with this disease.

Steroids are the mainstay of management for symptomatic sarcoidosis and have been successfully used to treat pancreatic involvement $[4,7,8,12]$. Following resection of pancreatic sarcoidosis in the absence of extrapancreatic involvement, however, it is unclear whether steroids are necessary for long term management. A few authors have reported long-term complete resolution of symptoms following surgical resection of the involved portion of the pancreas without the use of adjuvant steroids $[2,9,11]$.

\section{Conclusion}

Pancreatic sarcoidosis is an extremely unusual presentation of the systemic disorder. The current case demonstrates that presentation can occur in the head, body or tail of the pancreas. Clinical and radiologic findings overlap with those of malignancy, making preoperative diagnosis difficult. Prognosis is generally good with long term remission reported following resection with or without corticosteroid therapy.

\section{References}

1. Mayne AIW, Ahmad J, Loughrey M, Taylor MA (2013) Sarcoidosis of the pancreas mimicking adenocarcinoma. BMJ Case Reports 2013.

2. Schauer R, Volker U, Kreuzmayr A (2011) An unorthodox pancreatic lesion in a young man presenting with jaundice. Gastroenterology 141: 1563.

3. Wijkstrom M, Bechara RI, Sarmiento JM (2010) A rare nonmalignant mass of the pancreas: case report and review of pancreatic sarcoidosis. Am Surg 76: $79-84$
4. Wellner U, Mattern D, Keck T (2008) Clinical challenges and images in GI Early peripancreatic and pulmonary sarcoidosis. Gastroenterology 135: 1864.

5. Harder H, Buchler MW, Frohlich B, Strobel P, Bergmann F, et al. (2007) Extrapulmonary sarcoidosis of liver and pancreas: a case report and review of literature. World J Gastroenterology 13: 2504-2509.

6. Caceres M, Sabbaghian MS, Braud R, Wilks S, Boyle M (2006) Pancreatic sarcoidosis: unusual presentation resembling a periampullary malignancy. Curr Surg 63: 179-185

7. Baroni RH, Pedrosa I, Tavemaraki E, Goldsmith J, Rofsky NM (2004) Pancreatic sarcoidosis: MRI features. J Magn Reson Imaging 20: 889-893.

8. Romboli E, Campana D, Piscitelli L, Brocchi E, Barbara G, et al. (2004) Pancreatic involvement in systemic sarcoidosis. A case report. Dig Liver Dis 36: 222-227.

9. Frank JL, Goldman M, Nathanson I, Pierangelo D, Kaufman JL, et al. (2001) Surgical management of pancreatic sarcoid. Eur J Surg 167: 68-72.

10. Bacal D, Hoshal VL Jr, Schaldenbrand JD, Lampman RM (2000) Sarcoidosis of the pancreas: case report and review of the literature. Am Surg 66: 675-678.

11. Brady MS, Garfein CF, Klimstra D, Brenann MF (1993) Sarcoidosis of the pancreas. J surg oncol 54: 132-137.

12. Bonhomme A, Dhadamus A, de Bie P, Van Hoe L, Baert AL (1997) Pancreatic involvement in systemic sarcoidosis: CT findings. J Radiol 80: 116-117.

13. Soyer P, Gottlieb L, Bluemke DA, Fishman E (1994) Sarcoidosis of the pancreas mimicking pancreatic cancer: CT features. Eur J Radiol 19:32-33.

14. Brady MS, Garfein CF, Klimstra D, Brennan MF (1993) Sarcoidosis of the pancreas. J Surg Oncol 54: 132-137.

15. Bhatia A, Kumar Y, Kathpalia AS (2009) Granulomatous inflammation in lymph nodes draining cancer: a coincidence or a significant association!. Int J Med Med Sci 1: 013-016. 